\title{
БАЙГАЛЬ НУУРЫН ЦУТГАЛ ГОЛУУДЫН ГИДРОХИМИ, ӨӨРӨӨ ЦЭВЭРШИХ ПРОЦЕССЫН СУДАЛГАА
}

\author{
Б.Батдулам ${ }^{1}$, О.Болормаа ${ }^{1}$, В.В.Хахинов ${ }^{2}$, М.Кавахигаши $^{3}$ \\ ${ }^{1}$ Химийн тэнхим, МУИС-ШУС, Улаанбаатар, Монгол улс \\ ${ }^{2}$ Биологийн тэнхим, Буриадын их сургууль, Буриад, ОХУ \\ ${ }^{3}$ Газарзуйн тэнхим, Токио хотын их сургууль, Токио, Япон улс \\ Цахим иуудан: bolormaа@nит.edu.mn
}

Редакциид ирүҮлсэн: 2016.02.23

Товч агуулга: Гольнн ус жил ирэх тусам байгалийн болон хүний хүчин зүйл, тэр дундаа хөдөө аж ахуй, үйлдвэржслт, уул уурхайн үйл ажсллагаанаас үүдэн өөрчлөгдөж байна. Монгол орнь гадаргын усны голлох эх үүсвэр нь Сэлэнгэ, Орхон, Туул гольин сав газрууд бөгөөд эдгээр голуудн нь дэлхийн хамгийн эртний иэнгэг уст нуур болох Байгаль нуур луу иутгадаг. Байгаль нуурын ус нь иутгал голуудын усны найрлага, иинж чанараас үл хамааран дэлхийн хамгийн иэнгэг уст нуур хэвээр хадгалагдаж байгаа нь олон эрдэмтдийн анхаарлын төвд байсаар байна. Энэ судалгааны ажлын гол зорилго нь Байгаль нуурын иутгал голуудын усны гидрохимийн үзүүлэлтийг тодорхойлж, Байгаль нуурт иутгал голууд хэрхэн нөлөөлж байгааг тодорхойлох, голын усны өөрөө иэээрших процессыг Үнэлэх юм. Судалгаанд Монгол Улсын нутаг дэвсгэрт харьялагдах Сэлэнгэ, Орхон, Туул, Хараа, Ерөө, Буур болон Шарын голууд хамрагдсан болно.

Судалгаанд усны ияахилгаан дамжуулах чанар (ЦДЧ), исэлдэн ангижрах потенциал (ИАП) болон ууссан хүчилтөрөгч (УХ) нь тус тус $0.194-0.294 \mathrm{mS} / \mathrm{cm},(-33.5)$ - $15.5 \mathrm{mB}, 5.54-11.0 \mathrm{мz/л}$ агуулгатай илэрсэн. Усны УХ - ийн агуулга Буур голоос авсан дээжсинд Монгол Улсын гадаргын усны стандарт (MNS:4586 - 1998; УХ>6 мг/л) - аас бага тодорхойлогдсон. Энэ нь Буур голын урсаи муу, замагжсаны улмаас агаарын хүчилтөрөгчийг шингээж чадахгүй байгааг илтгэнэ. Усны хатуулаг нь зөөлөн, зөөлөвтөр усны ангид багтаж (А.О.Алекины ангилал), эрдэсжилтийн хэмжээ нь дунд зэргийн эрдэсжилттэй (А.М.Овчинниковын ангилал) байгаа нь судалгаанаас харагдлаа.

Усны микроэлементүYдээ $\mathrm{Al}$, Si, Fe - ийн агуулга бусад элементүҮдээс харьиангуй өндөр байгаа нь дэлхийн ияаридас дахь агуулга, хөрсний элэгдэл зэрэг байгалийн хүчин зүйл болон газар ашиглалт, уул уурхайн үйл ажиллагаа, үйлдвэржсилт зэрэг хүний хүчин зүйлээс үүдэлтэй байх магадлалтайг харуулж байна. Дээж авсан бүс нутагт нүҮрс болон алтны уурхай, ус иэвэрлэх байгууламжууд байрлах бөгөөд энэ нь Монгол орны хөдөө аж ахуй, газар тариалангийн төв хэсэг юм. Хэдий тийм ч, усны $\mathrm{pH}, \mathrm{NO}_{3}$ ион болон элементийн агуулга нь Монгол Улсын гадаргын усны стандарт (MNS:4586 1998) - аас хэтрээгүй байгаа нь сав газрын усны урсаи, хур тунадас болон гүний усны тэжээгдэл сайн, голын усны өөрөө иэвэриих процесс хангалттай байгааг харуулж байна. Мөн голын усны чанарыг Үнэлэх ҮҮднээс усны чанарын индексийг тооџоолон үзэхэд, Орхон гол дээр хамгийн өндөр илэрсэн нь дээж авах үед хур бороо ихтэй, гол үерлэсэн, хөдөө аж ахуйн үйл ажиллагаанаас үүдсэн бохирдол, бохир ус иэвэрлэх байгууламжаас гарч байгаа бүрэн иэвэриээгүй ус зэргийн нөлөөнөөс ҮҮдэлтэйг харуулж байна.

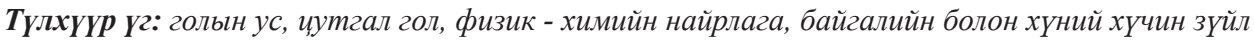




\section{ОРШИЛ}

Томоохон сав газрын голын усны чанарт хөдөө аж ахуй, уул уурхайн олборлолт, хотжилт, үйлдвэржилт болон бохир ус цэвэрлэх байгууламжаас гарах бүрэн цэвэршээгүй ус ихээхэн нөлөөлж байна. Технологийн эрин үе эхлэхтэй холбогдуулан байгаль орчин доройтолд орж хүний хүчин зүйлээс үүдэн экологийн тэнцвэрт байдал алдагдаж байна. Хил дамнан орших Сэлэнгэ мөрөн болон Байгаль нуурын сав газрын экологийн тэнцвэр нь хүрээлэн буй орчны бохирдлын гол үзүүлэлт болж байгаатай холбогдуулан Монгол орны томоохон усан сүлжээ Байгаль нуурт хэрхэн нөлөөлж байгааг тодорхойлох нь чухал ач холбогдолтой юм. Байгаль орчны аюулгүй байдал тэр дундаа усан орчны экосистем нь хүний болон байгалийн хүчин зүйлээс үүдэн доройтож байгаа нь олон судалгаагаар тодорхойлогдож байгаa [1] - [3] ч Байгаль нуур нь дэлхийн хамгийн цэнгэг уст нуур хэвээр байгаа нь эрдэмтдийн анхаарлыг татсаар байна.

Байгаль нуурын сав газрын ус, хөрс, биологи, геологийн судалгааг 1700 - аад оноос эхлэн хийснээс Байгаль нуурт цутгал голуудын шинж чанар хэрхэн нөлөөлж байгааг тодорхойлох судалгаа 1990 - ээд оноос хойш эрчимтэй хийгдэх болсон. Монгол, Оросын хамтарсан судлаачдын баг Сэлэнгэ мөрний сав газрын усны горим, усны гидрохимийн судалгаа, ионы урсцыг тодорхойлон олон бүтээл хэвлүүлсэн байдаг. Тухайлбал, Сэлэнгэ мөрний сав газарт харьяалагдах голуудын усны химийн найрлагыг судлах ажил 1973 оноос эхэлж Монгол Улсын Их Сургууль (МУИС) - ийн судлаачдын баг сав газрын усны унаган төрхийг тогтоон, усны бохирдол, байгаль экологийн талаар судалгаа хийсэн байдаг [2] - [5]. 2005, 2006 онуудад Ионг - Жон Лий, Б.Мэндбаяр болон бусад судлаачид хил дамнасан усны чанарын судалгааг хийж, Монгол орны хойд хэсэг дэх голын усны найрлага нь Туул голын сав газарт байрлах алтны уурхайн үйл ажиллагаанд ихээхэн өртсөн тул цаашид судалгааг илүу гүнзгийрүүлэн гадаргын усыг хамгаалах шаардлагатайг дурдсан байдаг [6]. Мөн 2008 онд хил дамнасан Сэлэнгэ мөрний судалгааг Юри Мөн, Ж.Лүнтэн болон бусад судлаачид усны нэгдсэн менежментийн судалгааг боловсруулах үүднээс хийж усны бохирдол нь байгалийн болон хүний хүчин зүйлээс үүдэлтэй гэж дүгнэн олон эх Үүсвэрээс бохирдож байгааг тодорхойлсон байдаг [7]. Монгол орны хойд хэсгийн гол мөрний судалгааг усны химийн найрлага төдийгүй байгаль цаг уурын нөхцөл дээр нь үндэслэн олон судалгаа хийгдсэн байдаг [8] - [12]. Гэсэн ч эдгээр судалгаа нь Сэлэнгэ мөрний сав газрын усны чанар найрлагыг судлан дүгнэсэн байдаг бол Байгаль нуурын усны чанар цутгал голоос Үүдэн хэрхэн өөрчлөгдөж байгааг, Байгаль нуур нь дэлхийн хамгийн цэнгэг уст нуур байгаагийн шалтгааныг тодорхойлох ажил хийгдэж байгаагүй. Манай судалгааны гол онцлог нь Байгаль нуурт Монгол орны хойд хэсгийн гол мөрд хэрхэн нөлөөлж байгааг тодорхойлох, цаашлаад эдгээр голуудын усны чанар найрлагыг тодорхойлсноор урсгал усны өөрөө цэвэрших процессыг үнэлэх явдал юм.

Монгол орон нь нийт 29 гол мөрдийн сав газарт хамаарагддаг бөгөөд усан сүлжээний дийлэнх нь Хойд мөсөн далайн ай савд хамаарах Сэлэнгэ мөрний усан сүлжээ юм. Орхон, Туул, Хараа, Ерөө, Буур, Шарын гол нь энэ усан сүлжээнд харьяалагдах бөгөөд эдгээр голуудын химийн найрлага нь Сэлэнгэ мөрнөөр дамжин Байгаль нуурт тодорхой хэмжээгээр нөлөөлж байдаг. Голын усны чанар, найрлага нь тухайн сав газрын голын усны хэрэглээ, сав газрын геологийн тогтоцын улмаар өөрчлөгдөх ч гадаргын урсгал ус нь урсах явцдаа байгалийн хүчин зүйлийн нөлөөлөл (седиментаци, микроорганизмын задрал, урсгалын хурд, температур, нарны гэрлийн 
нөлөөлөл гэх мэт) - өөр өөрөө цэвэрших процесст ордог. Өөрөө цэвэрших процесст нөлөөлөх хүрээлэн буй орчны чухал үзүүлэлтэд голын усны тэжээгдэл, урсгалын хурд зэрэг багтана.

Голын ус нь хур тунадас болон гүний усаар тэжээгддэг. Сэлэнгэ мөрний сав газар,
Хангай, Хэнтий, Хөвсгөлийн ууланд буух хур тунадасны хэмжээ 350 - 400 мм, харин Орхон, Хараа голын сав газруудад 250 - 300 мм байна [13]. Монгол орны газарзүйн онцлог, байгалийн тогтоц зэргээс хамааран гүний ус нь харилцан адилгүй тархацтай байдаг (зураг 1).

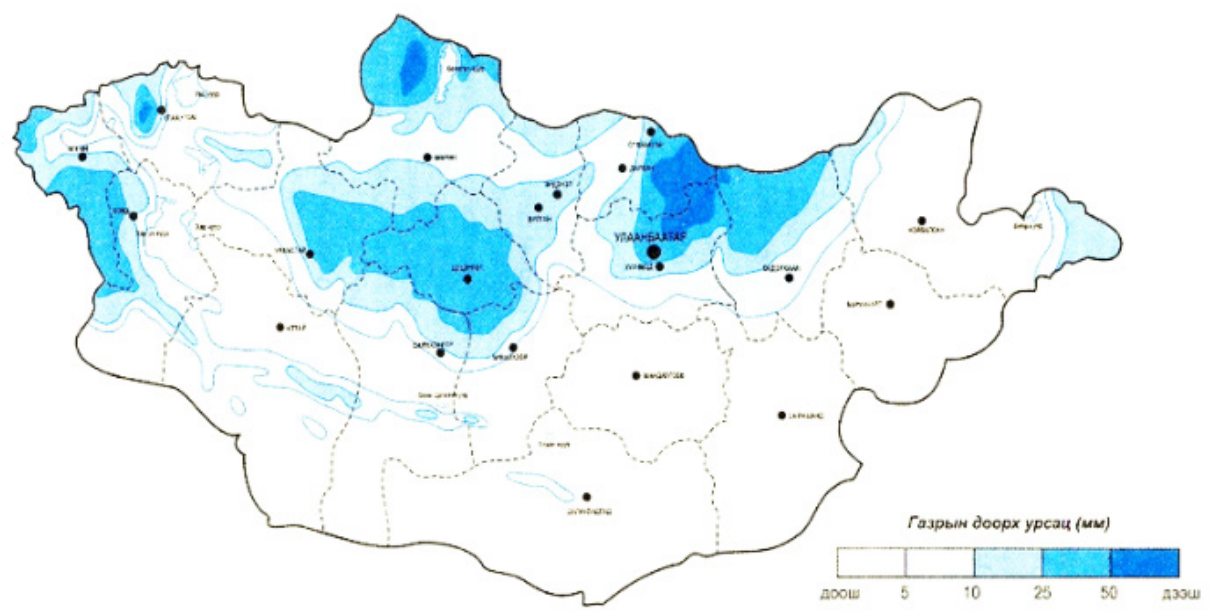

Зураг 1. Монгол улсын гүний усны тархалт [13]

Баруун болон хойд хэсгийн нутгаар гүний усны тархалт ихтэй бол өмнө болон зүүн хэсгийн нутгаар тархац нь харьцангуй бага байна. Сэлэнгэ, Орхон, Хараа, Ерөө, Туул голын сав нутгаар гүний ус нь 5 - 50 мм - ийн хооронд урсацтай байгааг ус, цаг уур, орчны шинжилгээний газраас мэдээлсэн [13].
Голуудын усны чанар, найрлагыг тогтоох, Монгол орны томоохон усан сүлжээнд хамаарах голуудын бохирдлын зэргийг тодорхойлох, өөрөө цэвэрших процессыг үнэлэх болон Байгаль нуурт эдгээр голын усны чанар хэрхэн нөлөөлөх боломжтойг судлах нь энэ судалгааны ажлын гол зорилго болно.

\section{СУДАЛГААНЫ МАТЕРИАЛ, АРГА АРГАЧЛАЛ}

Сэлэнгэ мөрөн болон Орхон гол, түүний зарим цутгалууд болох Туул, Хараа, Шарын гол, Ерөө, Буур голоос 16 дээжийг 2014 оны 8 - р сард авч гидрохимийн шинжилгээг хийсэн. Усны дээжийг Монгол - Орос хоёр улсын хил /Сэлэнгэ мөрөн/ - ээс Улаанбаатар хот чиглэлийн дагуу голын урсгал өөд авсан ч Байгаль нуурт нөлөөлөх нөлөөллийг судлах үүднээс урсгалыг уруудах чиглэлээр хэлэлцүүлэг хийсэн болно. Дээж авсан цэгийн байшил болон дээжний кодыг зураг 2, хүснэгт 1 - т тус тус үзүүлэв. 


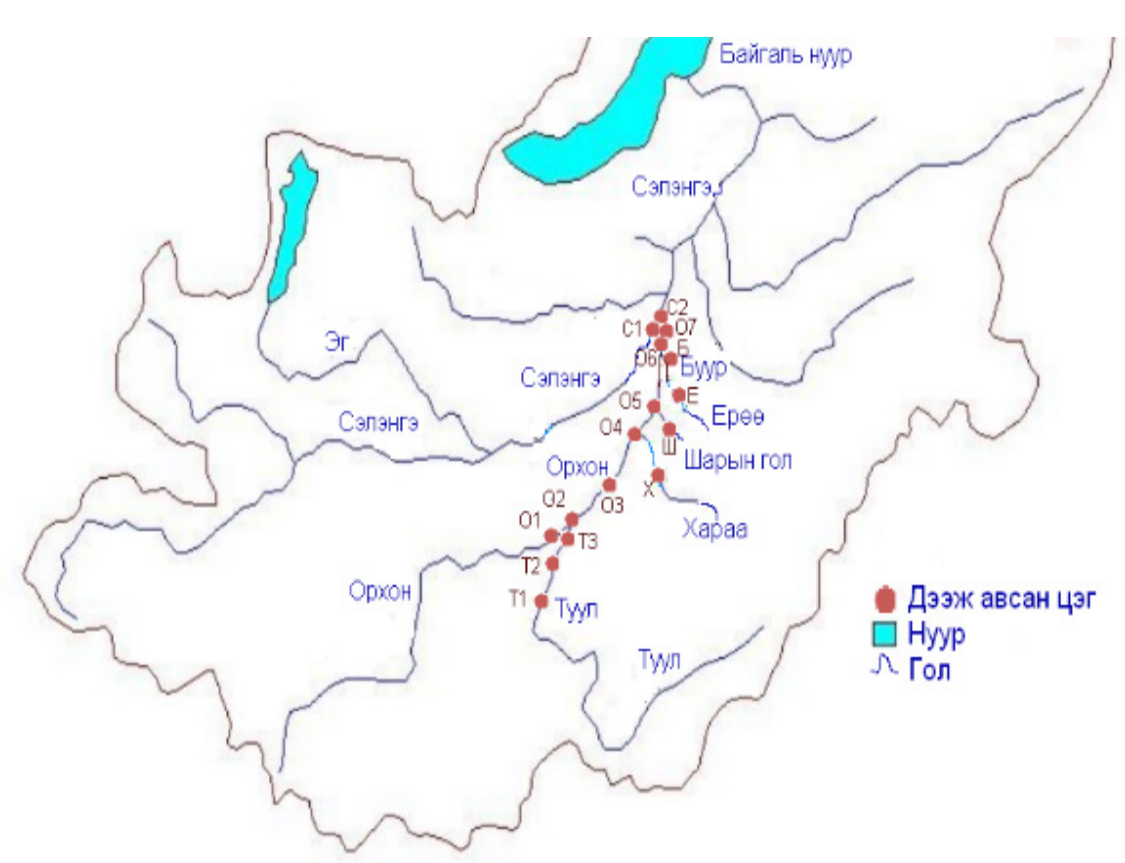

Зураг 2. Дээж авсан иэгийн байриил

Хүснэгт 1.

Дээжний байриил, код

\begin{tabular}{|c|c|l|}
\hline Д/д & Код & \multicolumn{1}{|c|}{ Дээж авсан газрын нэр } \\
\hline 1 & Т1 & Туул гол (Лүн сум) \\
\hline 2 & Т2 & Туул гол (Заамар сум) \\
\hline 3 & Т3 & Туул гол (Орхонтуул сум) \\
\hline 4 & О1 & Орхон гол (Орхонтулл сум) \\
\hline 5 & О2 & Орхон, Туул голын бэлчир \\
\hline 6 & О3 & Орхон гол (Орхоны гүүр, Сант сум) \\
\hline 7 & Х & Хараа гол (Дархан /гүүр/) \\
\hline 8 & О4 & Орхон Хараа голын бэлчир (Хушаат сум) \\
\hline 9 & Ш & Шарын гол (Орхон сум) \\
\hline 12 & О5 & Орхон Шарын голын бэлчир \\
\hline 10 & Е & Ерөө гол (Хушаат сум) \\
\hline 11 & Б & Буур гол (Сүхбаатар хот) \\
\hline 13 & О6 & Орхон гол (Сүхбаатар хот) \\
\hline 14 & О7 & Орхон гол (Орхон Сэлэнгэ голын бэлчир) \\
\hline 15 & С1 & Сэлэнгэ гол (Орхон Сэлэнгэ голын бэлчир) \\
\hline 16 & С2 & Сэлэнгэ мөрөн (Монгол-Орос хил) \\
\hline
\end{tabular}

Судалгаанд усны дээжийг зориулалтын дээж авагч багаж (Ван Дорн усны дээж авагч, Япон) - аар голын усны дунд хэсгээс авч дээжийн байршлыг байршил тогтоогч багаж (GPS Garmin 60CSX, Тайван) ийн тусламжтайгаар тэмдэглэж авсан.
Гидрохимийн шинжилгээнд зориулан 1л дээжийг полиэтилен саванд авч, мөн элементийн анализад зориулан 200 мл дээжийг концентрацтай давсны хүчлээр бэхжүүлэн савлаж авсан. Дээж авах үедээ газар дээр нь усны физик-химийн $-68-$ 
үзүүлэлтүүд болох $\mathrm{pH}$, температур, исэлдэн ангижрах потенциал (ИАП), ууссан хүчилтөрөгч (УХ), цахилгаан дамжуулах чанар (ЦДЧ), нийт ууссан хатуу хэсэг (HУXX), давслагийг мультипараметр багаж (Hanna НI 9828, АНУ) - ийн тусламжтайгаар тодорхойлсон.

Усны ерөнхий химийн шинжилгээг эзлэхүүний болон жингийн аргаар МУИС - ийн Хүрээлэн буй орчин судлалын лабораторид хийж гүйцэтгэсэн бол элементийн шинжилгээ Индукцийн Холбоот Плазмын Атом Цацаргуулалтын Спектрометр (ICP - AES) - ээр Японы Токио Хотын Их Сургуулийн Газар зүй, байгаль орчны лабораторид тус тус хийж гүйцэтгэсэн. Судалгаанд эзлэхүүний анализын аргаар зонхилох ионууд, ерөнхий хатуулаг, эрдэсжилт, исэлдэх чанар (ИЧ) ыг, спектрофотометрээр биоген нэгдлүүдийг тус тус тодорхойлсон [14] [15].

Усны чанар, бохирдлын зэргийг үнэлэх зорилгоор усны чанарын индексийг тооцоолон олдог [10], [18]. Усны чанарын индексийг /Wqi/ дараaх томъёогоор илэрхийлж судалгаанд хамрагдсан голуудад тооцоолон үзсэн.

$$
W_{q i}=\frac{\sum_{i} \frac{C_{i}}{p l_{i}}}{n}
$$

Үүнд: $C_{i}$ - бохирдуулагч $(i)$ элементийн агуулга, мг/л; $p l_{i}$ - Үндэсний Стандартын Газраас /1998/ тогтоосон бохирдуулагч (i) элементийн усан дахь зөвшөөрөгдөх дээд агуулга, мг/л; $n$ - бохирдлын нийт үзүүлэлтийн тоо болно.

Усны чанарын үнэлгээнд УХ, биологийн хэрэгцээт хүчилтөрөгч, химийн хэрэгцээт хүчилтөрөгч, аммони $\left(\mathrm{NH}_{4}^{+}\right)$, нитрат $\left(\mathrm{NO}_{3}^{-}\right.$ ) , нитрит $\left(\mathrm{NO}_{2}^{-}\right)$болон бусад бохирдуулагч элементүүдийг хамааруулан тооцоолж Wqi - ийн агуулгаар I. маш цэвэр $(<0.3)$; II. цэвэр (0.3 - 0.9); III. бага бохирдолтой (0.9 - 2.5); IV. бохирдолттой $(2.5-4.0)$; V. их бохирдолттой (4.0 - 6.0); VI. бохир (6.0 - 10.0); VII. маш бохир (>10) гэж ангилна [10], [16].

\section{ҮР ДУН ХЭЛЭЛЦУУЛЭГ}

\section{Усны гидрохимийн анализ}

Усны физик - химийн үзүүлэлтүүдийг хүснэгт 2, зураг 3 - т тус тус багцлан харуулав.

Гольн усны рН, температур, ИАП, УХ-н агуулга $/ S F=3$ /

Хүснэгт 2.

\begin{tabular}{|c|c|c|c|c|c|c|}
\hline Д/д & Код & $\mathrm{pH}$ & $\mathrm{T},{ }^{\circ} \mathrm{C}$ & ИАП, $\mathrm{MB}$ & УХ, мг/л & ЦДЧ, $\mathrm{mS} / \mathrm{cm}$ \\
\hline 1 & $\mathrm{~T} 1$ & 7.90 & 17.2 & 14.7 & 9.19 & 0.196 \\
\hline 2 & $\mathrm{~T} 2$ & 8.00 & 19.8 & 18.0 & 8.72 & 0.332 \\
\hline 3 & $\mathrm{~T} 3$ & 8.20 & 21.7 & 6.90 & 9.13 & 0.345 \\
\hline 4 & $\mathrm{O} 2$ & 8.40 & 21.4 & -33.5 & 9.98 & 0.281 \\
\hline 5 & $\mathrm{O} 3$ & 8.10 & 20.8 & 7.60 & 8.32 & 0.276 \\
\hline 6 & $\mathrm{X}$ & 8.40 & 19.2 & -21.5 & 9.14 & 0.277 \\
\hline 7 & $\mathrm{O} 4$ & 8.50 & 19.7 & -27.2 & 8.42 & 0.267 \\
\hline 8 & Ш & 8.40 & 17.5 & -12.6 & 8.81 & 0.307 \\
\hline 9 & $\mathrm{O} 5$ & 8.20 & 20.1 & -16.1 & 8.09 & 0.257 \\
\hline 10 & $\mathrm{E}$ & 7.70 & 17.0 & -9.00 & 8.45 & 0.078 \\
\hline 11 & Б & 7.90 & 22.0 & -2.60 & $4.78^{*}$ & 0.960 \\
\hline 12 & $\mathrm{O} 6$ & 7.90 & 20.0 & 15.9 & 6.76 & 0.195 \\
\hline 13 & О7 & 7.80 & 21.3 & 10.6 & 5.92 & 0.194 \\
\hline 14 & $\mathrm{C} 7$ & 7.80 & 20.6 & 13.3 & 5.54 & 0.201 \\
\hline
\end{tabular}

*Монгол Улсын гадаргын усны стандарт (MNS:4586 - 1998) - с бага (Ууссан хүчилтөрөгч нь зуньь улиралд $>6$ мг/л)

SF-утгат иифрр 


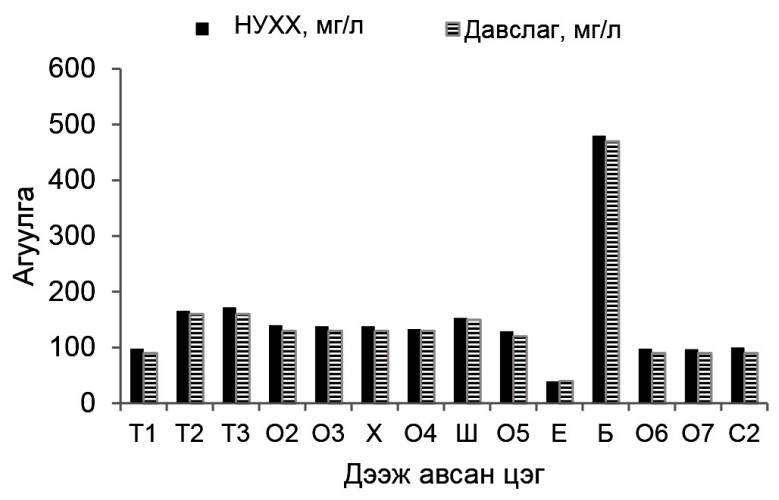

Зураг 3. Голын усан дахь НУХХ, Давслагийн агуулга

Голын усны орчин нь сул шүлтлэг (pH: 7.70 - 8.50) байгаа нь Монгол Улсын гадаргын усны стандарт (MNS 4586 - 1998: 6.5 - 8.5) - аас хэтрээгүй байсан. Голын усны температур нь $17.2-22.0^{\circ} \mathrm{C}, \mathrm{УX} \mathrm{нь} 4.78$ 9.14 мг/л, ИАП нь -33.5 - 15.9 мV агуулгатай илэрсэн. Дээж авсан О2, Х, О4, Ш, О5, Е болон Б цэгүҮдэд ИАП нь сөрөг утгатай илэрсэн. Буур гол (Б) дээрх УХ - н агуулга нь Монгол Улсын гадаргын усны стандарт (MNS 4586 - 1998: УХ - 6 мг/л) - аас бага байгаа нь Сүхбаатар хотын хог хаягдлаар бохирдсон, урсгал багатай, замагжсанаас агаарын хүчилтөрөгчийг өөртөө шингээж чадахгүй байгаатай холбоотой.

Голын усны ЦДЧ нь 0.078 - $0.960 \mathrm{MS} / \mathrm{cm}$, НУХХ нь 39 - 480 мг/л, давслаг нь 40 - 470 мг/л агуулгатай байлаа. ЦДЧ, НУХХ болон давслаг нь өөр хоорондоо шууд хамааралтай байгаа нь судалгаанаас харагдаж байна. Ерөө гол (Е) - оос авсан дээжинд ЦДЧ, НУХХ болон давслаг нь хамгийн бага агуулгатай байсан бол Буур гол (Б) - оос авсан дээжинд хамгийн их агуулгатай байсан. Ерөө голын ус нь бусад голуудтай харьцуулахад эрдэсжилт багатай бол Буур гол нь Сүхбаатар хотын гэр хорооллын айлуудын дундуур урсахдаа органик болон ахуйн бохирдлоор бохирдож байсан [17] нь ЦДЧ, НУХХ болон давслагийн агуулгаар тодорхойлогдлоо. Туул гол нь Лүн сум (T1) - аас Заамар сум (Т3) руу урсах явцад усан дахь ЦДЧ, НУХХ болон давслагийн агуулга өссөн үзүүлэлтэй байсан бол Орхон гол (O2) руу буурч, цаашид урсах явцад огцом өөрчлөлт илрээгүй.

Голын усан дахь зонхилох ионуудын агуулгыг Пиперийн диаграмаар зураг 4 - т харуулав.

Буур гол (Б) - оос авсан усны дээжинд $\mathrm{Mg}^{2+}$ ион, Сэлэнгэ мөрөн (C1, С2) - өөс авсан усны дээжинд $\mathrm{Ca}^{2+}$ ион давамгайлсан бол бусад голуудад аль нэг ион давамгайлаагүй байсан. Сэлэнгэ аймгийн Сүхбаатар хотын дэргэдээс авсан Орхон гол (О6) - ын усны дээж нь холимог, харин бусад дээж авсан цэгүҮдэд голын ус нь $\mathrm{HCO}_{3}^{-}$ион давамгайлсан байна. Эдгээрээс зонхилох ионуудын агуулга нь О6 цэгт $\mathrm{SO}_{4}^{2-}+\mathrm{Cl}^{-}$ болон $\mathrm{Ca}^{2+}+\mathrm{Mg}^{2+}$ төрлийн бол бусад цэгүүдэд $\mathrm{CO}_{3}{ }^{2-}+\mathrm{HCO}_{3}{ }^{-}$болон $\mathrm{Ca}^{2+}+\mathrm{Mg}^{2+}$ төрлийн ус болох нь ажиглагдлаа.

Зонхилох ионуудын агуулгаас үзэхэд, Буур голын ус нь гидрокарбонатын ангийн магнийн бүлгийн 1 - р төрлийн ус $\left(\mathrm{HCO}_{3}^{-}\right.$ $>\mathrm{Ca}^{2+}+\mathrm{Mg}^{2+}$ мг-экв/л) - д багтаж байгаа бол бусад голууд гидрокарбонатын ангийн кальцийн бүлгийн 1 - p төрлийн усанд багтаж байна. 


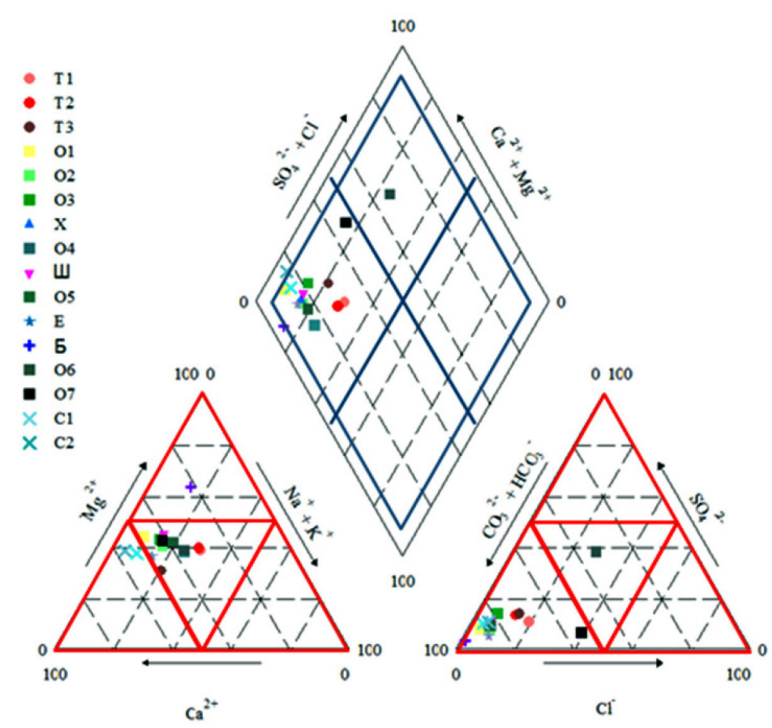

Зураг 4. Гольн усан дахь зонхилох ионуудын агуулга

Голын усны зонхилох ионуудын агуулгыг бусад судлаачдын үр дүн [2], [17] - тэй харьцуулан хүснэгт 3 - т харуулав.

ХУснэгт 3.

Бусад судлаачдын үр дүнтэй харьиуулсан харьиуулалт, $S F=3,4$

\begin{tabular}{|c|c|c|c|c|c|c|}
\hline Зонхилох ион & $\mathrm{Ca}^{2+}$ & $\mathrm{Mg}^{2+}$ & $\mathrm{Na}^{+}+\mathrm{K}^{+}$ & $\mathrm{HCO}_{3}^{-}$ & $\mathrm{SO}_{4}^{2-}$ & $\mathrm{Cl}^{-}$ \\
\hline \multicolumn{7}{|l|}{ Орхон } \\
\hline 2009 & 28.46 & 8.76 & 18.32 & 140.2 & 12.0 & 14.6 \\
\hline 2010 & 28.06 & 8.62 & 20.98 & 139.2 & 14.6 & 12.0 \\
\hline $2013 *$ & 33.70 & 20.6 & 17.90 & 174.3 & 15.4 & 15.4 \\
\hline \multicolumn{7}{|l|}{ Xараa } \\
\hline 2009 & 37.10 & 11.6 & 32.90 & 183.0 & 16.0 & 14.2 \\
\hline 2010 & 38.10 & 16.4 & 24.50 & 177.0 & 10.0 & 21.3 \\
\hline 2013* & 42.40 & 26.9 & 18.60 & 183.1 & 18.4 & 6.50 \\
\hline \multicolumn{7}{|l|}{ Шарын гол } \\
\hline 2009 & 57.10 & 15.8 & 18.10 & 229.0 & 13.0 & 10.7 \\
\hline 2010 & 54.10 & 17.0 & 34.30 & 244.0 & 45.6 & 21.3 \\
\hline $2013 *$ & 46.90 & 31.4 & 19.78 & 193.4 & 20.7 & 8.30 \\
\hline \multicolumn{7}{|l|}{ Ерөө гол } \\
\hline 2009 & 18.00 & 2.40 & 10.5 & 82.40 & 5.00 & 3.60 \\
\hline 2010 & 16.00 & 2.40 & 9.200 & 73.20 & 5.00 & 3.60 \\
\hline $2013 *$ & 13.50 & 6.07 & 4.930 & 91.50 & 4.40 & 5.30 \\
\hline \multicolumn{7}{|l|}{ Сэлэнгэ } \\
\hline 2006 & 50.60 & 18.2 & 27.90 & 164.0 & 108 & 14.2 \\
\hline 2007 & 50.98 & 32.2 & 16.74 & 61.23 & 29.2 & 6.93 \\
\hline $2013 *$ & 31.10 & 13.1 & 4.500 & 137.3 & 13.4 & 4.60 \\
\hline
\end{tabular}

*Энэ судалгааны үр дүн 
Зонхилох ионуудын агуулгыг дээж авсан цэгтэй адил цэгээс дээж авсан өмнөх судалгааны үр дүн [2], [17]-тэй харьцуулан судласан. Сэлэнгэ, Орхон голын ионуудын агуулга өссөн үзүүлэлттэй байсан бол Хараа, Шарын гол, Ерөө голын химийн найрлагын өөрчлөлт бага ажиглагдсан. Усанд $\mathrm{HCO}_{3}^{-}$ионы агуулга давамгайлж байлаа.

Зонхилох ионуудын агуулга өссөн үзүүлэлттэй байгаа нь байгаль орчны нөхцөл, жилийн дундаж хур тунадас, температур зэрэг байгалийн хүчин зүйл, уул уурхайн олборлолт, хөдөө аж ахуй, мал аж ахуй зэрэг хүний хүчин зүйлийн нөлөөллөөр усны найрлага өөрчлөгдсөнөөс үүдсэн байх боломжтой юм. Тиймээс жилийн дундаж хур тунадасны нийлбэр, жилийн дундаж температурыг мэдсэнээр зонхилох ионуудын агуулгын өссөн шалтгааныг тодорхойлох боломжтой.

Дээж авсан цэгүүдийн ойролцоох ус, цаг уур, орчны шинжилгээний газрын станцаас
2006 - 2013 оны хоорондох жилийн дундаж температур, хур тунадасны мэдээллийг авахад, жил ирэх тусам хур тунадасны хэмжээ Орхон (2006 онд 289.1 мм, 2013 онд 485.7 мм), Орхонтуул (2006 онд 298.0 мм, 2013 онд 393.0 мм), Сүхбаатар (2006 онд 286.8 мм, 2013 онд 296.3 мм) станцуудад нэмэгдсэн үзүүлэлттэй байсан [13]. Харин жилийн дундаж температур нь 2006-2009 онд ихсээд 2013 онд буурсан үзүүлэлттэй байсан. Орхон (2006, 2008, 2013 онуудад $\left.0.1,0.5,-4.2^{\circ} \mathrm{C}\right)$, Орхонтуул $(2006,2008$, 2013 онуудад $\left.0.6,0.9,-3.5^{\circ} \mathrm{C}\right)$, Сүхбаатар $\left(2006,2008,2013\right.$ онуудад $\left.0.7,1.7,-3.1^{\circ} \mathrm{C}\right)$ орчим жилийн дундаж температур бага, хур тунадсаар хөрс угаагдан голын усан дахь зонхилох ионы агуулгыг өөрчилсөн байх магадлалтай юм [13].

Голын усан дахь ерөнхий хатуулаг (EX), исэлдэх чанар (ИЧ), эрдэсжилтийн агуулгыг хүснэгт 4 - т үзүүлэв.

Гольнн ерөнхий хатуулаг, исэлдэх чанар (ИЧ), эрдэсжилтийн агуулга $/ S F=2 ; 3$ /

ХУснэгт 4.

\begin{tabular}{|c|c|c|c|c|c|c|c|c|c|}
\hline \multirow{2}{*}{ Д/д } & \multirow{2}{*}{ Код } & EX & ИЧ & Эрдэсжилт & \multirow{2}{*}{ Д/д } & \multirow{2}{*}{ Код } & EX & ИЧ & Эрдэсжилт \\
\hline & & мГ-ЭКВ/л & мг/л & мг/л & & & МГ-ЭКв/л & мГ/л & мг/л \\
\hline 1 & T1 & 2.5 & 6.80 & 134 & 9 & Ш & 3.5 & $11.6^{*}$ & 200 \\
\hline 2 & $\mathrm{~T} 2$ & 3.2 & $10.8^{*}$ & 220 & 10 & O5 & 2.7 & 7.60 & 182 \\
\hline 3 & T3 & 3.4 & $16.0^{*}$ & 223 & 11 & $E$ & 3.5 & 8.80 & 118 \\
\hline 4 & $\mathrm{O} 1$ & 3.2 & 6.40 & 183 & 12 & Б & 1.5 & $22.8^{* *}$ & $518 * *$ \\
\hline 5 & $\mathrm{O} 2$ & 3.2 & 9.20 & 215 & 13 & O6 & 2.9 & 7.60 & 129 \\
\hline 6 & $\mathrm{O} 3$ & 2.9 & 7.60 & 169 & 14 & O7 & 2.4 & 7.60 & 183 \\
\hline 7 & $\mathrm{X}$ & 3.0 & 7.60 & 185 & 15 & $\mathrm{C} 1$ & $3.9^{* *}$ & $14.8^{*}$ & 149 \\
\hline 8 & $\mathrm{O} 4$ & 2.7 & 7.20 & 216 & 16 & $\mathrm{C} 2$ & 2.7 & $10.0^{*}$ & 133 \\
\hline
\end{tabular}

*Монгол Улсын гадаргын усны стандарт (MNS 4586 - 1998) - аас хэтэрсэн Үр дүн

**Хамгийн өндөр агуулга

Усны ЕX нь дээж авсан цэгүүдэд 1.5 - 3.9 мг-экв/л агуулгатай тодорхойлогдсон

[17] - [19]. О.А.Алекины усны хатуулгийн ангиллаар маш зөөлөн $(<1.50)$; зөөлөн $(1.51$ - 3.00); зөөлөвтөр (3.01 - 5.00); хатуувтар (5.01 - 7.00); хатуу (7.01 - 9.00); маш хатуу (>9.00) гэсэн ангид хуваан авч үздэг бөгөөд Туул, Орхон, Хараа, Шарын гол болон Буур голын усны дээжүүд зөөлөн, Сэлэнгэ болон Ерөө голын усны дээжүүд зөөлөвтөр усны ангид багтаж байна. Голын усны ИЧ -ын агуулга хамгийн ихдээ Буур гол (Б) -оос авсан дээжинд илэрсэн. Зарим дээж авсан цэг (Т2, Т3, Ш, Б, С1, С2) -үүдэд ИЧ нь Монгол Улсын гадаргын усны стандарт (MNS 4586 - 1998: ИЧ - 10 мг/л) -аас хэтэрсэн байгаа нь тогтоогдлоо. Үүний шалтгаан нь усанд хялбар исэлддэг байгалийн гаралтай бодисуудын хэмжээ их, ахуйн гаралтай бохирдуулагчаар бохирдсон 
байх магадлалтайг харуулж байна [15].

Хүснэгт 4 - с харахад, дундаж эрдэсжилт нь Буур голд хамгийн их, Ерөө голд хамгийн бага тус тус 518 мг/л, 118 мг/л байсан. Буур голын эрдэсжилт, ионы агуулга их байгаа нь 2001 оны байдлаар Улаанбаатар Төмөр замын харьяа Нефть хангамжийн баазаас шатах тослох материал алдагдаж улмаар хөрсөөр нэвчин Буур голд орсноос голын ус органик гаралтай бодисоор бохирдсоноос үүдэлтэй байх магадлалтай юм [17]. А.М.Овчинниковын эрдэсжилтийн агуулгаар Сэлэнгэ, Орхон, Туул, Хараа, Шарын гол, Ерөө гол нь бага эрдэсжилттэй, Буур гол нь харьцангуй их эрдэсжилттэй ангид багтаж байна [19]. Орхон гол Туул голтой нийлэхээс өмнө (O1) ИЧ, эрдэсжилт багатай байсан бол нийлсний дараа $(\mathrm{O} 2)$ өссөн үзүҮлэлттэй байлаа. Мөн үүнтэй нэгэн адилаар Орхон

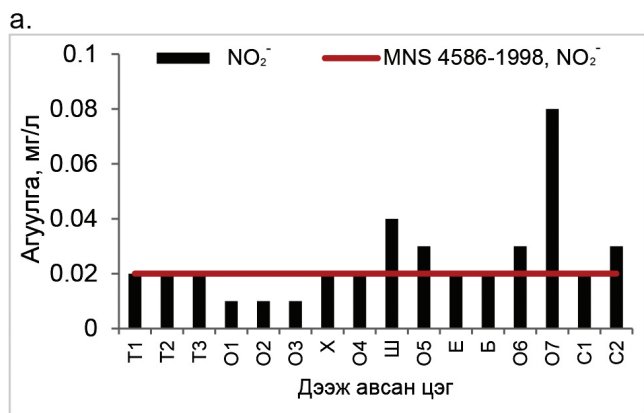

B.

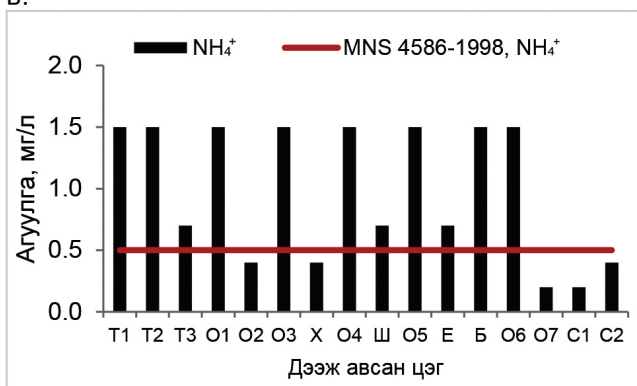

голын эрдэсжилт нь Хараа гол нийлсний дараа өссөн бол Шарын гол нийлсний дараа (O6) буурсан үзүүлэлттэй байна. Орхон Сэлэнгийн бэлчирээс авсан Сэлэнгэ мөрөн (C1) - ний эрдэсжилт 149 мг/л байсан бол цааш урсахдаа буурсан байна.

Голын усан дахь биоген нэгдлүүдийн агуулгыг зураг 5 - т үзүүлэв.

Нитрит $\left(\mathrm{NO}_{2}^{-}\right)$ион голын усанд 0.01 0.08 мг/л агуулгатай байлаа. Шарын гол, Орхон, Сэлэнгэ мөрнөөс авсан дээж (Ш, O5, $\mathrm{O} 6, \mathrm{O} 7, \mathrm{C} 2)$ - д $\mathrm{NO}_{2}^{-}$ионы агуулга Монгол Улсын гадаргын усны стандарт (MNS 4586 - 1998) - аaс 1.5 - 4 дахин их байгаа нь тогтоогдлоо. Шарын гол болон Орхон гол нь ахуйн гаралтай бохирдуулагчаар бохирдсоноос, харин Сэлэнгэ мөрөн нь Орхон голын нөлөөллөөс үүдэлтэй $\mathrm{NO}_{2}^{-}$ ионы агуулга их байна гэж үзэж байна.

б.
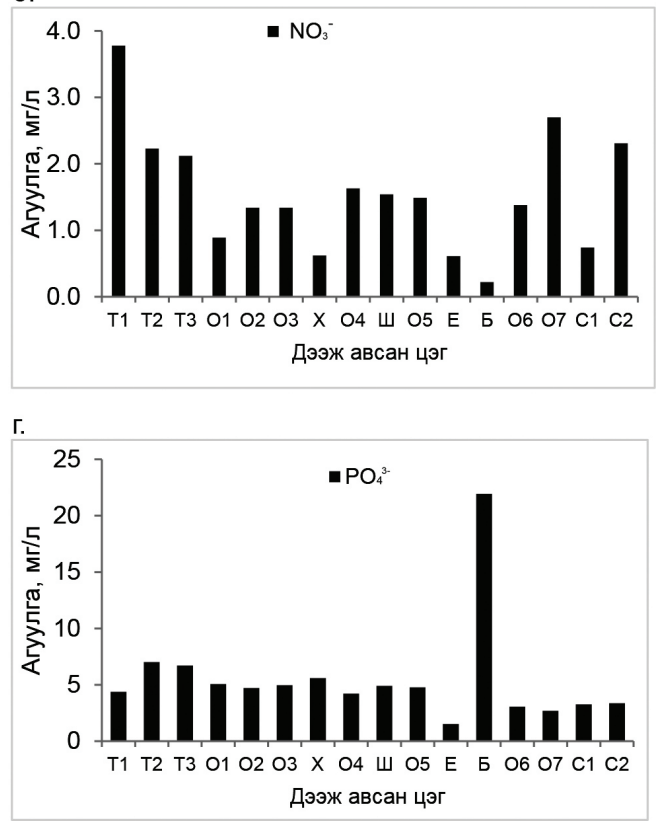

Зураг 5. Усны биогенийн нэгдлүудийн агуулга

а. Нитрит ион, б. Нитрат ион, в. Аммони ион, г. Фосфат ион

Нитрат $\left(\mathrm{NO}_{3}^{-}\right)$ионы агуулга Монгол Улсын гадаргын усны стандарт (MNS 4586:1998, $\mathrm{NO}_{3}^{-}-9$ мг/л) - аас хэтрээгүй,
Туул гол (Т1) усанд агуулагдах $\mathrm{NO}_{3}^{-}$ионы агуулга өндөр байсан. Харин Буур гол дээр хамгийн бага утгатай байлаа. Усанд 
$\mathrm{NO}_{3}^{-}$ионы агуулга ямар хэмжээгээр илэрч байгаагаас усны өөрөө цэвэрших процессын талаар мэдээлэл авах боломжтой байдаг [20]. Туул гол нь урсац, хур тунадасны тэжээгдэл (Лүнгийн станцын мэдээгээр 2013 оны дунадаж хур тунадасны хэмжээ нь 299 мм [13]) сайн, УХ (8.72 - 9.19 мг/л) -н агуулга өндөр, $\mathrm{NO}_{3}^{-}$ион (3.8 мг/л) их илэрч байгаа нь голын ус өөрөө цэвэрших процесст хангалттай орж байна гэж үзэж болно. Харин Буур гол нь ахуйн бохирдлоор бохирдсон, УХ (4.78 мг/л) - н агуулга бага, замагжсан нь цэвэрших процесс хангалтгүй байгааг илтгэж байна.

Зураг 5 - с харахад, голын усанд аммони $\left(\mathrm{NH}_{4}^{+}\right)$ион 0.2 - 1.5 мг/л агуулгатай байгаа нь, Т1, Т2, Т3, O1, O3, O4, Ш, O5, Е, Б болон О6 цэгүүдэд Монгол Улсын гадаргын усны стандарт (MNS 4586 - 1998) - аaс хэтэрсэн агуулгатайг илтгэнэ. Усны бохирдолтыг илэрхийлдэг нэг Үзүүлэлт болох $\mathrm{NH}_{4}^{+}$ион нь органик болон ахуйн гаралтай бохирдуулагчаар ус бохирдсон байх магадлалтайг харуулдаг [20]. Мөн
Туул голд алтны үйлдвэрлэлийн үйл ажиллагаа хүчтэй нөлөөлснөөс голын ус ихээр булингартан $\mathrm{NH}_{4}^{+}$ион их илэрсэн байх боломжтой [21]. Голын усны дээжийг хур бороо их, үерлэсэн үед авсан учраас голын ус эрэг хавийн хог хаягдал, хөрсийг их хэмжээгээр угаасны улмаас усан дахь $\mathrm{NH}_{4}^{+}$ионы агуулга өндөр гарсан.

Голын усан дахь фосфат $\left(\mathrm{PO}_{4}^{3-}\right)$ ионы агуулга 1.52 мг/л (Ерөө гол) - аас 21.94 мг/л (Буур гол) байлаа. Буур голын усны дээжинд $\mathrm{PO}_{4}^{3-}$ ионы агуулга өндөр байгаа нь УХ (4.48 мг/л) бага, замаг ихээр ургаснаар илэрч байна. Мөн голын усан дахь $\mathrm{PO}_{4}^{3-}$ ионы агуулга Монгол Улсын гадаргын усны стандараас өндөр байгаа нь хөрс чулуулгийн угаагдал, хөдөө аж ахуй, уул уурхай, хотын хог хаягдал, ус цэвэрлэх байгууламжаас гарч буй бүрэн цэвэршээгүй ус зэргээс үүдэлтэй байх боломжтой юм [22] - [23].

Голын усны микроэлемент (Al, $\mathrm{Si}, \mathrm{Fe}$, $\mathrm{Pb}, \mathrm{B}, \mathrm{Cr}, \mathrm{Mn}, \mathrm{Mo}$, Ni болон $\mathrm{Zr}$ ) - ын дундаж агуулгыг хүснэгт 5 - т багцлан харуулав.

ХХснэгт 5.

Микроэлементийн дундаж агуулга $/ S F=1 ; 2 ; 3 ; 4 /$

\begin{tabular}{|c|c|c|c|c|c|c|c|c|c|c|c|}
\hline № & Гол & $\begin{array}{c}\mathrm{Al}, \\
\text { мг/л }\end{array}$ & $\begin{array}{c}\mathrm{Si}, \\
\text { мг/л }\end{array}$ & $\begin{array}{c}\mathrm{Fe}, \\
\text { мг/л }\end{array}$ & $\begin{array}{c}\mathrm{Pb}, \\
\mathrm{мг/л}\end{array}$ & В, мг/л & $\begin{array}{c}\mathrm{Cr}, \\
\text { мг/л }\end{array}$ & $\begin{array}{l}\mathrm{Mn}, \\
\text { мг/л }\end{array}$ & $\begin{array}{l}\text { Мо, } \\
\text { мг/л }\end{array}$ & $\mathrm{Ni}$, мг/л & $\mathrm{Zr}$, мг/л \\
\hline 1 & Сэлэнгэ & 0.154 & 5.535 & 0.0700 & 0.000 & 0.147 & 0.004 & $0.01 *$ & 0.014 & 0.001 & 0.044 \\
\hline 2 & Орхон & 0.144 & 5.015 & 0.134 & 0.0020 & 0.175 & 0.003 & 0.005 & 0.0090 & 0.005 & 0.010 \\
\hline 3 & Туул & $0.244 *$ & 5.103 & 0.0600 & 0.0030 & $0.215^{*}$ & 0.004 & 0.008 & 0.011 & 0.002 & 0.0080 \\
\hline 4 & Xapaa & 0.110 & 5.880 & 0.140 & 0.000 & 0.180 & $0.006^{*}$ & 0.006 & 0.013 & 0.004 & 0.0090 \\
\hline 5 & Шарын & 0.238 & 6.970 & $0.210 *$ & 0.0010 & 0.185 & $0.006^{*}$ & 0.002 & 0.016 & 0.003 & 0.0090 \\
\hline 6 & Epөe & 0.196 & 5.640 & 0.150 & $0.012 *$ & 0.142 & 0.005 & 0.004 & 0.0040 & $0.007 *$ & 0.010 \\
\hline 7 & Буур & 0.117 & $10.80 *$ & 0.0900 & 0.000 & 0.208 & 0.004 & 0.001 & 0.018* & 0.003 & $0.019 *$ \\
\hline
\end{tabular}

*Хамгийн өндөр агуулга

Хүснэгт 5 - түзүүлсэн микроэлементийн дундаж агуулга нь Монгол Улсын гадаргын усны стандарт (MNS 4586 1998) - аaс хэтрээгүй. Микроэлементүүд нь аливаа ордын дагалдах элемент болж газрын гүнд үүсээд тухайн газрыг ухаж хөндөх үед газрын гадаргад ил гарч ирснээрээ химийн урвал исэлдэн ангижрах процесст орж хувиран өөрчлөгдөж орчныхоо хөрс, усанд нөлөөлж улмаар гадаргын усанд үүссэн хүнд металлууд урсгалынхаа дагуу зөөвөрлөгдөж байна [17]. Усан дахь Al, Si, Fe, В - ын агуулга бусад элементүүдээс харьцангуй өндөр байгаа нь хөрс, чулуулгийн уусалт, дэлхийн царцдас дахь дундаж агуулгаас үүдэлтэй болно. Хартугалгын агуулга Ерөө голд хамгийн өндөр илэрсэн бол Сэлэнгэ, Хараа, Буур голуудад илрээгүй. Микроэлементийн анализаар дээж авсан голуудад $\mathrm{Cr}$ - ын агуулга 0.003 мг/л (Орхон) - аaс 0.006 мг/л (Хараа, Шарын гол) байсан. 2009 онд 
Шарын голын усанд хүнд металлын анализ хийхэд $\mathrm{Cr}$ - ын агуулга Монгол Улсын гадаргын усны стандарт (MNS 4586-1998 Cr:0.05 мг/л) - аaс их үзүүлэлттэй байсан [17]. Харин 2013 оны бидний судалгаанд $\mathrm{Cr}$ - ын агуулга өндөр илрээгүй. Манганы агуулга Сэлэнгэ мөрөнд, молибден болон цирконы агуулга Буур голд харьцангуй өндөр илэрсэн. Харин никелийн агуулга Ерөө голд харьцангуй их байсан. Ерөө, түүний бүх цутгал голуудын хөндийд алт олборлолт явагдаж байгаагаас голын ус хүнд металлаар бохирдсон гэж тогтоосон байна [17]. Бидний судалгаанд Ерөө голын усан дахь хартугалга, никелийн агуулга бусад голуудаас харьцангуй өндөр тодорхойлогдсон. Голын усан дахь микроэлементийн дундаж агуулгыг харьцуулан харахад, олон эх үүсвэртэй байх магадлалтай юм. Үүнийг хүснэгт 6 - д үзүүлэв.

Гольин уснь бохирдльнн эх ҮҮсвэр [7]

\begin{tabular}{|l|l|}
\hline Байршил & Бохирдлын эх үүсвэр \\
\hline $\begin{array}{l}\text { Сэлэнгэ мөрөн } \\
\text { (Монгол-Оросын хил) }\end{array}$ & Хил орчмын нутаг дэвсгэрийн болон Орхон голын үр нөлөө \\
\hline Сэлэнгэ мөрөн & $\begin{array}{l}\text { Ус цэвэрлэх байгууламж, сууршьмал айл өрх, мал сүрэг, Ерөө, Хараа, } \\
\text { Шарын гол, Туул голын сав газар дахь алт олборлолтын нөлөө }\end{array}$ \\
\hline $\begin{array}{l}\text { Орхон - Сэлэнгэ } \\
(\text { нийлсний дараа) }\end{array}$ & $\begin{array}{l}\text { Ус цэвэрлэх байгууламж, сууршьмал айл өрх, мал сүрэг, Ерөө, Хараа, } \\
\text { Шарын гол, Туул голын сав газар дахь алт олборлолтын нөлөө }\end{array}$ \\
\hline Орхон гол & $\begin{array}{l}\text { Ус цэвэрлэх байгууламж, сууршьмал айл өрх, мал сүрэг, Ерөө, Хараа, } \\
\text { Шарын гол, Туул голын сав газар дахь алт олборлолтын нөлөө }\end{array}$ \\
\hline Ерөө гол & Алт олборлолт, сууршьмал айл өрх, мал сүрэг \\
\hline Шарын гол & Мал сүрэг, сууршьмал айл өрх, алт олборлолт \\
\hline Хараа гол (Дархан) & Сууршьмал айл өрх, мал сүрэг, газар тариалангийн талбай \\
\hline
\end{tabular}

Ус цэвэрлэх байгууламжаас гарах бүрэн цэвэршээгүй ус, уул уурхай, хөдөө аж ахуй зэрэг хүний хүчин зүйлээс үүдэлтэй бохирдуулагчаас үүдэн усны химийн найрлага өөрчлөгдсөн байх боломжтой нь хүснэгт 6 - с харагдаж байна.

\section{Усны чанарын индекс}

Усны чанарын индексийг томьёогоор голын усанд хэмжсэн химийн үзүүлэлтүүдээс Монгол Улсын гадаргын усны стандарт (MNS 4586-1998) - аac хэтэрсэн $\mathrm{NO}_{2}^{-}, \mathrm{NH}_{4}^{+}-\mathrm{H}$ агуулгаар тооцоолоход Туул, Орхон, Сэлэнгэ, Хараа, Шарын гол, Ерөө, Буур голуудад тус бүр $5.2,10.2,1.85,0.9,1.7,1.2$ болон 2 гарсан. Усны чанарын индексээр тооцоолон Орхон голын усны чанарыг үнэлэхэд, их бохирдолттой ангид багтаж байсан. Үүний шалтгаан нь Орхон голын уснаас дээж авахад голын ус үерлэсэн, булингартай, усанд их хэмжээний ионууд ууссантай холбоотой байх магадлалтай. Хараа голын ус нь цэвэр усны ангид хамаарч байсан бол бусад голууд нь бага бохирдолттой усны ангид хамаарч байсан.

Усны дээжийн химийн найрлага хөрсний угаагдлаар өссөн байх магадлалтай ба зарим голын сав газарт уул уурхайн үйл ажиллагаа эрчимтэй явагдаж байгаа, хөдөө аж ахуйн болон хотжилт, үйлдвэржилт, цэвэрлэх байгууламжийн бүрэн цэвэршээгүй бохир ус нь гадаргын усны найрлаганд нөлөөлж байх магадлалтайг харуулж байна. Гэсэн хэдий ч, усны чанар, найрлага нь голын усны цэвэрших процесс хангалттай байгааг харуулж байна.

\section{Голын усны өөрөө цэвэрших процесс}

Голын усны өөрөө цэвэрших процессын чухал үзүүлэлтэд голын химийн найрлагаас гадна усны урсац, тэжээгдэл, нарны гэрлийн тусгал, УХ - н агуулга зэрэг багтдаг. Төв, Сэлэнгэ аймгийн хувьд 2010 
- 2013 оны жилийн дундаж температур нь $-1.57^{\circ} \mathrm{C},-1,43^{\circ} \mathrm{C}$ бол жилийн дундаж хур тунадасны нийлбэр нь 258.7 мм, 310.6 мм бөгөөд жил ирэх тусам температур буурч, хур тунадасны хэмжээ ихэссэн үзүүлэлттэй байжээ [13]. Харин 2011 оны ус, цаг уур, орчны шинжилгээний газрын голын усны урсац буюу өнгөрөлтийн мэдээллийн сангаас авсан үзүүлэлтээс харахад, жилийн дундаж урсац Сэлэнгэ мөрөн, Орхон, Туул, Хараа, Шарын гол болон Ерөө голын хувьд $68.79,26.10,8.9,4.27,2.6$, болон $0.99 \mathrm{~m}^{3} /$ сек байна [13].

Сэлэнгэ, Орхон, Туул голын урсац харьцангуй сайн (8.9 - 68.79 м³ $^{3} /$ сек), 2010 - 2013 оны байдлаар хур бороо ихтэй (181.8 - 393 мм), гүний усны тэжээгдэл сайтай (гүний усны урсац: 5 - 50 мм) байгаа нь өөрөө цэвэрших процесс хангалттай сайн явагдах боломжтойг харуулж байна. Энэ нь УХ, $\mathrm{NO}_{3}^{-}$ионы агуулга их,

\section{ДҮГНЭЛТ}

Байгаль нуурт цутгадаг голууд болох Сэлэнгэ, Орхон, Туул, Хараa, Ерөө, Буур болон Шарын голын усны химийн найрлага, усны чанарын судалгааны үр дүнд дараах дүгнэлтэд хүрлээ.

Шинжилгээнд хамрагдсан голын ус О.А.Алекины ангиллаар зөөлөн (1.5 - 3.0 мг-экв/л), зөөлөвтөр (3.3 - 3.5 мг-экв/л) усны ангид хамаарагдаж, гидрокарбонатын ангийн кальци, магнийн бүлгийн нэгдүгээр төрлийн усанд багтаж байгааг тогтоолоо. Голын усны чанарт ус цэвэрлэх байгууламжаас гарч буй бүрэн цэвэршээгүй ус, уул уурхай, хөдөө аж ахуй болон ахуйн гаралтай бохирдуулагчид нөлөөлж байгаа нь судалгааны үр дүнгээс харагдлаа. Сэлэнгэ, Орхон, Туул голын хувьд усны чанар өөрөө цэвэрших процесс хангалттай, гидрокарбонатын ангийн кальцийн бүлгийн цэвэр усанд багтаж байгаа нь голын ус өөрөө цэвэрших процесст орж байгааг харуулж байна. Хараа, Ерөө, Шарын голын урсац харьцангуй бага (0.99 - 4.2 м³/сек), хур тунадасны болон гүний усны тэжээгдэл сайн байгаа нь голын усны өөрөө цэвэрших процесс тодорхой хэмжээгээр явагдаж байгааг харуулж байна. Мөн УХ, биоген элементийн агуулга шинжилсэн дээжүүдэд өөрчлөлт ажиглагдсан нь өөрөө цэвэрших процесст орж байгаагийн баталгаа болно.

Харин Буур гол замагжсаны улмаас УХ - н агуулга (4.78 мг/л) Монгол Улсын гадаргын усны стандартаас бага, нарны энергийн тусгал бага, хотын хог хаягдлаар бохирдсон, фосфатын агуулга өндөр (21.9 мг/л), нитрат ионы агуулга бага (0.2 мг/л) байгаагаар өөрөө цэвэрших процесс хангалтгүй байгааг харуулж байна. харин Буур голын хувьд хангалтгүй явагдаж байгаа нь усны химийн үзүүлэлт (УХ, $\mathrm{NO}_{3}^{-}$ион гэх мэт) болон голын урсац, хур борооны тэжээгдэл зэргээр тодорхойлогдож байна. Усны химийн найрлаганд цутгал голын нөлөө илэрч байгаa нь Орхон голын усны эрдэсжилтийн үр дүнгээс тодорхойлогдож байна. Байгаль нуурт эдгээр цутгал голын шинж чанар нөлөөлөх магадлалтай тул үүнийг цаашид нарийвчлан судлах шаардлагатай. Цаашид Сэлэнгэ, Орхон, Туул, Хараa, Ерөө, Буур болон Шарын голын усны химийн найрлагын нөлөө Байгаль нуурын усны чанарт хэрхэн нөлөөлж байгааг ус - седиментийн хоорондын хамаарлаар тогтоох зүйтэй гэж үзлээ. 


\section{ТАЛАРХАЛ}

Хээрийн судалгааны ажлыг зохион Шинжлэх Ухааныг дэмжих санд талархал байгуулж амжилттай гүйцэтгэхэд илэрхийлье.

санхүүгийн дэмжлэг үзүүлсэн Японы

\section{Ашигласан бүтээлийн жсагсаалт}

1. Khazheeva.Z.I, Tulokhonov.A.K and Dashibalova.L.T, "Seasonal and Spatial Dynamics of TDS and Major Ions in the Selenga River Basin," Water Resources, vol. 34, no. 4, pp. 444-449, 2007.

2. Munguntsetseg.A, "Hydrochemistry of river "Selenge", " pp. 13-16, 22-35, 2006.

3. Munguntsetseg.A, Samarina.A.V, Shpeizer.G.M, "Selenge river hydrological mode in Mongolia," Proceeding of Mongolian Academy of Sciences, vol. 15, 1976.

4. Munguntsetseg.A, Ariunjargal.J, Enkhtsetseg.Sh, "The results of Tuul river pollution study," NUM print, vol. 3, 1997.

5. Munguntsetseg.A, Otgonbayar.G, Ganbat.S, "Pollution study of Orkhon river," NUM print, vol. 3, pp. 139-154, 2001.

6. Young-Joon.L, Seong-Taek.Y, Mendbayar.B et al, Joint research between Korea and Mongolia on water quality and contamination of transboundary watershed in Northern Mongolia, Korea: Korea Environment Institute, 2006, pp. 1-73.

7. Yuri.M, Ick.H, Lunten.J, "Integrated Water Management Model on the Selenge River Basin Status Survey and Investigation (Phase I)," Korea Environment Institute, Korea, 2008.

8. Bazarova.J.G., Dorzhieva.S.G, Bazarov.B.G, et al, "Hydrochemical characteristics of Selenge River and its tributaries on the Territory of Mongolia," Mongolian Journal of Biological Sciences, vol. 2, no. 1, pp. 39-42, 2004.

9. Andrew.S, Sudeep.C, Sean.E, Dampil.T, et al, "Impacts of Gold Mining and Land Use Alterations on the Water Quality of Central Mongolian Rivers," Integr Environ Manag , vol. 1, pp. 365-373, 2005.

10. Davaa.G, Oyunbaatar.D and Michiyagi Sugita, "Surface waters of Mongolia," vol. 1, pp. 69-82, 2007.

11. S. Chalov, M. Lychagin, and N. Kasimov, "Human impacts on Water and Sediment Quality of Selenga River system," Geophysical Research Abstracts, vol. 14, pp. 1-14, 2012.

12. Sergey R. Chalov, Aleksandr S. Zavadsky, Jambaljav Yamkhin et al, "Suspended and dissolved matter fluxes in the upper Selenga river basin," Geography, Environment, Sustainability, vol. 2, no. 5, pp. 78-94, 2012.

13. Data from Information And Research Institute Of Meteorology, Hydrology And Environment.

14. Bulgan.T, "Methodology of water chemical analysis," pp. 9-48, 52-59, 142-150, 2008.

15. Tuvaanjaw.G, Munkhzul.D and Dolgorjav.L, "Water chemistry and calculation of results," pp. 11-22, 25-37,47, 51-55, 56-59, 65-57,, 2006.

16. Orchir.A, "Surface water quality assessment and modeling A case study in the Tuul river, Ulaanbaatar city, Mongolia," pp. 1-12, 2008.

17. Javzan.Ch, "Hydrochemistry of Orkhon river basin," pp. 19-73, 2011.

18. A.A.Reznikov, E.P.Mulikovskayaa, Methods of analysis of natural waters, Goskhimizdat: State scientific and technical publishing literature on geology and subsoil protection, 1954, pp. 110-116, 132-140, 155-159, 167-174, 162-167.

19. Alekin.O.A, Basics of hydrochemistry, Leningrad: Gidrometeoizdat, 1970, pp. 235.

20. Tuvaanjav.G, Mongolians development works and studies of water quality, Ulaanbaatar: Undraga print Co.,Ltd, 2011, pp. 28-31.

21. Dolgorsuren.G, Baldandorj.Ts, Gantuul.Sh et al, The research compilation for development of integrated water resources management plan for the Orkhon River Basin", Ulaanbaatar, 2012, pp. 51-103. 
22. Dorj.D, Environmental chemistry, Ulaanbaatar: NUM print, 2006, pp. 171-198.

23. Dolgorsuren. G, Chagnaa.N, Gantuul.Sh et al, he research compilation for development of integrated water resources management plan for the Tuul River Basin", Ulaanbaatar, 2012, pp. 58-105. 


\title{
HYDROCHEMICAL STUDY AND SELF PURIFICATION PROCESS OF TRIBUTARIES OF LAKE BAIKAL
}

\author{
Batdulam Battulga $a^{1}$ Bolormaa Oyuntsetseg ${ }^{1}$, \\ Viacheslav Victorovich Khakhinov', Masayuki Kawahigashi ${ }^{3}$ \\ ${ }^{\prime}$ National University of Mongolia, Department of Chemistry, Ulaanbaatar, Mongolia \\ ${ }^{2}$ Buryat State University, Department of Biology, Buryatia, Russia \\ ${ }^{3}$ Tokyo Metropolitan University, Department of Geography, Tokyo, Japan \\ *E-mail: bolormaa@num.edu.mn
}

\begin{abstract}
A chemical component of river water has been changing each year caused by many factors, including anthropological activities, agriculture, industry, mining, etc. The major surface water resources of Mongolia in the basin include the Selenge, Orkhon and Tuul Rivers. The basin ultimately drains into Lake Baikal (the world's deepest fresh water lake) in Russia. Lake Baikal water is still clean and fresh lake in the world despite the influence of tributaries. This study aimed to determine and evaluate hydrochemical parameters of river water which flows into Lake Baikal. Study area covered in Mongolian part of Selenge River, Orkhon, Tuul, Kharaa, Yeruu and Shariin River.

The water electrical conductivity (EC), oxidation reduction potential (ORP) and dissolved oxygen (DO) were measured $194 \mu \mathrm{S} / \mathrm{cm}$ to $294 \mu \mathrm{S} / \mathrm{cm},-33.5 \mathrm{mV}$ to $15.5 \mathrm{mV}$ and $5.54 \mathrm{mg} / \mathrm{l}$ to $11.0 \mathrm{mg} / \mathrm{l}$ respectively. The water DO was within the acceptable concentrations specified in the Mongolian National Standard of natural water (MNS 4586 - 1998 DO >6 mg/l) except from sampling from Buur wetland near the Sukhbaatar city in Mongolia. The water hardness were classified very soft by A.O.Alekin's classification. Therefore, the water mineralization was ranged from 79.24 to $311.2 \mathrm{mg} / \mathrm{l}$ and most of river waters include in moderately mineralized water by A.M.Ovchinnicov's classification.

The results of elements illustrate that high concentration of $\mathrm{Al}, \mathrm{Si}$ and $\mathrm{Fe}$ in water is conducted anthropogenic activity, land use, dissolution of minerals, soil erosion, mining and light industrial activity of river basin. The coal mining, gold mining and waste water treatment plant were located in the most of sampled river basin. It is prove that high concentration of some elements in water. However, the $\mathrm{pH}$, the nitrate-nitrogen $\left(\mathrm{NO}_{3}^{-}-\mathrm{N}\right)$ and elemental composition of water were within the acceptable concentrations specified in the Mongolian National Standard of natural water (MNS 4586 - 1998). It is related to the ground water discharge, current, flow velocity and climate effect of river basin. The assessment of surface water quality for natural waters, was done using water quality index. The high value of water quality index calculated in the Orkhon River due to waste water treatment plant, agriculture and mining etc.
\end{abstract}

Key words: river water, tributary, physico - chemical component, natural and anthropogenic activity. 